
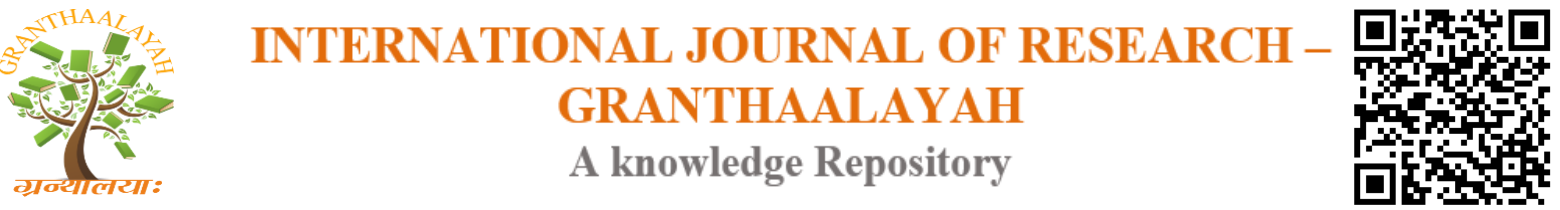

Science

\title{
EFFECTS OF DIFFERENT RATES OF ORGANIC AND INORGANINC FERTILIZER ON GROWTH AND YIELD COMPONENTS OF POTATO (SOLANUM TUBEROSUM L.) IN JIMMA ARE, SOUTH WEST ETHIOPIA
}

\author{
Amana Mama ${ }^{1}$, Jemal Jeylan ${ }^{2}$, Abebe Woldesenbet Aseffa *3 \\ $1,2,{ }^{* 3}$ Department of Horticulture and Plant Sciences, Jimma University College of Agriculture \\ and Veterinary Medicine (JUCAVM), P.O.Box 307, Jimma, ETHIOPIA
}

DOI: https://doi.org/10.29121/granthaalayah.v4.i11.2016.2429

\section{ABSTRACT}

The experiment was conducted under field condition at Jimma University College of Agricultures and Veterinary Medicine (JUCAVM) to determine the Effects of Different Rate of Organic and Inorganic Fertilizer on Growth and yield Components of Potato (Solanum tuberosumL).The experiment design used was randomized complete block design (RCBD). The experimental treatments were replicated three times. A Potato cultivar 'Jalene' was grown combined with Farmyard manure and nitrogen (F0NO), (F20N70), (F0N35),(F0N70), (F20N35), (F20N0) as a treatment.. Data were recorded on Potato leaf area, plant height, leaf length, leaf number, leaf diameter, stem diameter and stem number. The result revealed that the combination of various level of Farmyard manure and nitrogen statistically ( $\leq \leq 0.05)$ affected leaf area, plant height, leaf length, leaf number, leaf diameter, stem diameter and stem number. The maximum values for leaf area, plant height, leaf length, leaf number, leaf diameter, stem diameter and stem number were recorded from (F0N70, F20N70, F0N70, F20N35, F20N0, F20N70, F20N0) respectively.However The minimum values of all the parameters were recorded from the control treatment (FO NO). From the study it could be concluded that Potato yield components were greatly affected by different rates of organic and inorganic fertilizers. The appropriate amount of different rates of fertilizers (farmyard manure and nitrogen) should be used to increase Potato growth and yield.

Keywords:

farmyard manure, nitrogen fertilizer, Potato, Crop yield.

Cite This Article: Amana Mama, Jemal Jeylan, and Abebe Woldesenbet Aseffa, "EFFECTS OF DIFFERENT RATES OF ORGANIC AND INORGANINC FERTILIZER ON GROWTH AND YIELD COMPONENTS OF POTATO (SOLANUM TUBEROSUM L.) IN JIMMA ARE, SOUTH WEST ETHIOPIA" International Journal of Research - Granthaalayah, Vol. 4, No. 11 (2016): 115-121. 


\section{INTRODUCTION}

Potato (Solanum tuberosum L.) is one of major crops contributing to the world's food security (Karam et al., 2009) ${ }^{[8]}$. It is the most popular tuber crops in the world. Potato is one of the most important field corps not only to its local consumption but also to increase meeting income through its exportation among different countries in the world (Kandil et al., 2011) ${ }^{[7]}$.

Fertilizers are one of the most important inputs of increasing the productivity of crops and modern varieties of different crops (Ali et al., 2009) ${ }^{[1]}$. Fertilizer application has important effects on the quality and yield of Potato (Leytem and Westermann, 2005) ${ }^{[9]}$. Potato is highly responsive to Nitrogen fertilizer and Nitrogen is usually the most limiting essential nutrient for Potatoes growth, especially on sandy soils (Errebhi et al., 1998) ${ }^{[4]}$. Nitrogen supply also plays an important role in the balance between vegetative and reproductive growth for Potato (White et al., 2007) ${ }^{[12]}$.

Appropriate fertilization was reported to increase the average fresh tuber, plant height, leaf number and tuber; weight per plant responded positively application and Leaf area increased (Kandil et al., 2011) ${ }^{[7]}$.

Organic material is used to prevent or improve the negative stresses effects in plants and yield decreasing. It is material to decrease soil salinity. Increase the organic matter, improve the soil structure and increase water and air permeability by root developing in soil. It is one the best used fertilizers (Hassanpanah and Azimi, 2012) ${ }^{[6]}$.

Many researchers have mentioned the beneficial effects of organic fertilizer including the increase of hydraulic conductivity, raising the water holding capacity, changing the soil $\mathrm{pH}$ (increase or decrease in the $\mathrm{pH}$, depending on soil type and characteristics of organic fertilizer), Asiegbu, J. E. \& Oikeh, S. (1995) ${ }^{[3]}$ elevating the soil aggregation and water infiltration, reducing the frequency of plant diseases. (Tagoe et al., 2008) ${ }^{[10]}$. So, the use of animal manure has been reported as a potential factor for better vegetative growth and increased tuber yield (Amir Ali Najm et al., 2005) ${ }^{[2]}$. the use of animal manure has been reported as a potential factor for better vegetative growth and increased tuber yield (Amir Ali Najm etal., 2005) ${ }^{[2]}$.The present study will determines the combine and comparative effects of farmyard manure and inorganic fertilizer (UREA and DAP) on the plant height, stem diameter, number of tiller per main stem, leaf numbers, number of secondary branch per main stem and leaf area of Potato.

Potato was introduced to Ethiopia in 1858 by the German Botanist, Schemper. Since then, Potato became an important garden crop in many parts of the country. In Ethiopia, about $70 \%$ of the available agricultural land is suitable for Potato production, which is located at an altitude of 1500 to 3000 meters above sea level with an annual rainfall between $600 \mathrm{~mm}$ and $1200 \mathrm{~mm}$ (Gebremedhin et al., 2008) ${ }^{[5]}$.

Low soil fertility is one of the most important constraints limiting potato production in Ethiopia. Fertility of most Ethiopian soils has already declined due to continuous cropping, abandoning of fallowing, reduced use of manure and crop rotation. In Ethiopia, national yield and variety trials data over several locations on different crop species clearly indicates that soil nutrient stress is 
the most significant factor controlling crop yield (Tamirie, 1989) ${ }^{[11]}$. Despite its importance as a food crop, the productivity of Potato is as low as 10t/ha mainly due to poor agronomic practices such as poor fertilization. Therefore, the objective of this study was to investigate effects of different rates of organic and inorganic fertilizer on growth and yield components of Potato (Solanum tuberosum L.) in Jimma area.

\section{MATERIALS AND METHODS}

Description the study area: The experiment was conducted at Jimma University College of Agricultures and Veterinary Medicine (JUCAVM) at field condition in 2016. The area is located in Oromia region, Jimma Zone south western part of Ethiopia which is geographically located at $7^{\circ}, 33^{\circ} \mathrm{N}$ Latitude and $36^{\circ} \mathrm{S}, 57 \mathrm{o}$ E longitude at altitude of 1710 meters above sea level (m.a.s.l) and $352 \mathrm{Km}$ from Addis Ababa. The mean maximum and minimum temperature are $26.8^{\circ} \mathrm{c}$ and $11.4^{\circ} \mathrm{c}$ respectively and the mean maximum and minimum humidity is $91.4 \%$ and $31.2 \%$ respectively. The area receives annual rain fall of $1500 \mathrm{~mm}$. The soil of the experimental site is characterized by well drained clay to silty clay with $\mathrm{P}^{\mathrm{H}}$ of 4.51(BPEDORS, 2000)

Experimental Materials: The experimental materials used were meter, rulers, pegs, hoe, rake, axes, , spades, shovel or fork, weighting balance, buckets, Potato seed tuber ('Jalene' cultivar), farm yard manure (FYM), and Nitrogen.

Treatments and Experimental Design: The research consists of six treatments including the control $\mathrm{T}_{1}$ (F0N0), $\mathrm{T}_{2}$ (F20N70), $\mathrm{T}_{3}$ (F0N35), $\mathrm{T}_{4}$ (F0N70), $\mathrm{T}_{5}$ (F20N35), $\mathrm{T}_{6}$ (F20N0). The treatments consists of Farmyard manure (FYM) at two level (0 and 20) ton/hectare and inorganic fertilizers (Nitrogen $\left(\mathrm{N}_{2}\right)$ in three level $(0,35 \%, 70 \%)$ of the recommended dose of $185 \mathrm{~kg} / \mathrm{ha}$ Urea on Nitosiol. The experiments were laid out as completely randomized block design (CRBD) replicated three times. Thus, there were $6 \times 3$ treatments, which were replicated three times, resulting in 18 experimental units. Therefore, totally 18 experimental units were established.

\section{EXPERIMENTAL PROCEDURES}

Farmyard manure (FYM) at two level (0\% and 20\%) ton/hectare and inorganic fertilizers (nitrogen $(\mathrm{N}))$ at three levels $(0 \%, 35 \%$, and $70 \%)$ were measured and prepared. The width and length of each plot was measured at $1 \mathrm{~m}$ and $1 \mathrm{~m}$, respectively. The distance between blocks and plots were $1 \mathrm{~m}$ and $0.5 \mathrm{~m}$ respectively. Spacing of $50 \mathrm{~cm}$ and $30 \mathrm{~cm}$ between rows and plants were measured respectively on each plot. And the total area used was $40.5 \mathrm{~m}^{2}$. After preparing and lining the plots, each plot was watered. Nine seed tubers ('Jalene' cultivar), were planted on each plot and a total of 162 planting materials were used.

\section{DATA COLLECTION AND ANALYSIS}

Three representative plants per plot were taken at random from center with respect to replicated treatments. Data was taken starting from three weeks after emergence up to $50 \%$ flowering of the plant. Number of tiller, Leaf number-per plant, Number of internodes and Number of $2^{\circ}$ branch per main stem at $50 \%$ flowering were counted and recorded. Plant height $(\mathrm{cm})$ was measured 
using meter at 45 days after emergence. The diameter of the main stem $(\mathrm{cm})$ was measured. Leaf area of plant in $\mathrm{cm}^{2}$ was collected through measuring length \&width of three plants with ruler. Based on the ANOVA results mean separation and significance was compared among treatments parameters were subjected to statistical analyses by one way ANOVA using statistix 8 user guide version 2. Based on the ANOVA results mean separation and significance was compared among treatments through least significance difference test at $\mathrm{P}<0.05$ level of probability.

\section{RESULTAND DISCISSION}

\section{LEAF AREA}

Analysis of variance showed that there were highly significant (at p-value of $<0.001$ ) difference on leaf length due to main of Nitrogen and interaction of FYM with nitrogen and there was no significant difference due to FYM. Statistical analysis of the data showed that leaf area of Potato crop was significantly affected by farmyard manure. The data (Table-1) revealed that the maximum $\left(26.633 \mathrm{~cm}^{2}\right)$ leaf area were recorded in (70) farmyard manure. The minimum (10.7 $\mathrm{cm}^{2}$ ) leaf area was recorded in controlled treatment. $\mathrm{T}_{2}, \mathrm{~T}_{3}, \mathrm{~T}_{5}$ and $\mathrm{T}_{6}$ were significantly not different from each other. However, leaf area of Potato increased as the quantity of farmyard manure increased this may be due to the nutrient composition of the farm yard manure. These findings are supported by the earlier work by Najm etal (2013).

Table1: Leaf Diameter, Leaf Length, Leaf Number, Plant Height, Steam Diameter and Steam Number as affected by different levels of Farmyard manure and Nitrogen Fertilizer

\begin{tabular}{llcccccc} 
Treatment & LA & LD & LL & LN & PH & SD & SN \\
\hline T (F0 N0) & $10.7^{\mathrm{c}}$ & $3.5333^{\mathrm{b}}$ & $4.5667^{\mathrm{c}}$ & $165.33^{\mathrm{c}}$ & $107.63^{\mathrm{b}}$ & $2.7417^{\mathrm{b}}$ & $1.6433^{\mathrm{c}}$ \\
T2 (F20N70) & $20.167^{\mathrm{b}}$ & $4.3700^{\mathrm{b}}$ & $6.2667^{\mathrm{ab}}$ & $164.93^{\mathrm{c}}$ & $128.88^{\mathrm{a}}$ & $5.1100^{\mathrm{a}}$ & $3.3000^{\mathrm{a}}$ \\
T3 (F0N35) & $19.567^{\mathrm{b}}$ & $4.2333^{\mathrm{b}}$ & $6.0000^{\mathrm{ab}}$ & $159.77^{\mathrm{c}}$ & $118.76^{\mathrm{ab}}$ & $4.5833^{\mathrm{a}}$ & $3.0000^{\mathrm{ab}}$ \\
T4 (F0N70) & $26.633^{\mathrm{a}}$ & $3.3767^{\mathrm{c}}$ & $6.6333^{\mathrm{a}}$ & $212.67^{\mathrm{ab}}$ & $122.45^{\mathrm{ab}}$ & $2.9967^{\mathrm{b}}$ & $2.2800^{\mathrm{bc}}$ \\
T5 (F20N35) & $17.533^{\mathrm{b}}$ & $4.3667^{\mathrm{b}}$ & $5.4433^{\mathrm{bc}}$ & $219.67^{\mathrm{a}}$ & $116.40^{\mathrm{ab}}$ & $3.2200^{\mathrm{b}}$ & $2.7000^{\mathrm{ab}}$ \\
T6 (F20N0) & $19.800^{\mathrm{b}}$ & $5.0533^{\mathrm{a}}$ & $5.8333^{\mathrm{ab}}$ & $208.67^{\mathrm{b}}$ & $119.22^{\mathrm{ab}}$ & $3.2667^{\mathrm{b}}$ & $3.3333^{\mathrm{a}}$ \\
\hline & & & & & & & \\
CV & 13.79 & 4.84 & 9.74 & 2.79 & 8.07 & 15.94 & 17.40 \\
LSD & 4.78 & 0.3659 & 1.0262 & 9.5833 & 17.449 & 1.0593 & \\
\hline
\end{tabular}

Means within the same column followed by different letter are significantly different at $\mathrm{P} \leq 0.05$; LA=Leaf Area, LD=Leaf Diameter, LL=Leaf Length, LN=Leaf Number, PH=Plant Height, $\mathrm{SD}=$ Steam Diameter, $\mathrm{SN}=$ Steam Number. $\mathrm{CV}=$ Coefficient of variance, $\mathrm{LSD}=$ Least significant difference. 
Table 2: interaction effects of Farm yard manure and Nitrogen on potato growth and yield components.

Source of Mean squares

$\begin{array}{lllllllll}\text { Variation } & \text { Df } & \text { LA } & \text { LD } & \text { LL } & \text { LN } & \text { PH } & \text { SD } & \text { SN }\end{array}$

Treatment 5

\begin{tabular}{|c|c|c|c|c|c|c|c|c|}
\hline Fym & & $\begin{array}{c}\text { NS } \\
0.180\end{array}$ & $\begin{array}{c}* * * \\
3.50242\end{array}$ & $\begin{array}{c}\mathrm{ns} \\
0.05894\end{array}$ & $\begin{array}{l}* * * \\
1540.12\end{array}$ & $\begin{array}{l}\mathrm{ns} \\
122.722\end{array}$ & $\begin{array}{l}\text { ns } \\
0.81281\end{array}$ & $\begin{array}{c}* * * \\
2.90405\end{array}$ \\
\hline Nit & & $\begin{array}{c}* * * \\
100.835\end{array}$ & $\begin{array}{c}* \\
0.35849\end{array}$ & $\begin{array}{c}* \\
2.36511\end{array}$ & $\begin{array}{c}\mathrm{ns} \\
11.46\end{array}$ & $\begin{array}{c}\text { ns } \\
232.420\end{array}$ & $\begin{array}{cc}* & * \\
0 & 1.92926\end{array}$ & $\begin{array}{c}\text { ns } \\
0.22541\end{array}$ \\
\hline $\begin{array}{c}\text { Fym+ } \\
\text { Nit }\end{array}$ & & $\begin{array}{r}* * * \\
96.428\end{array}$ & $\begin{array}{c}* \\
0.73496\end{array}$ & $\begin{array}{c}* \\
1.50711\end{array}$ & $\begin{array}{r}* * * \\
5038.13\end{array}$ & $\begin{array}{r}\mathrm{ns} \\
74.591\end{array}$ & $4.54395^{* *}$ & $\begin{array}{r}* \\
1.53785\end{array}$ \\
\hline $\begin{array}{l}\text { Error } \\
\text { Total }\end{array}$ & $\begin{array}{l}10 \\
17\end{array}$ & 1.462 & 0.04961 & 0.41811 & 24.22 & 12.807 & 0.22628 & 0.81236 \\
\hline
\end{tabular}

\section{PLANT HEIGHT}

Plant height was affected by various integrated use of farmyard manure and nitrogen that indicated in Table-1. The data manifested after statistical analysis that its height has significantly affected by the combined used of fertilizer. Statistical analysis of the data showed that all treatments were not significantly different from each other. Data (Table-1) revealed that, the maximum $(128.88 \mathrm{~cm})$ plant height was recorded in treatment of FYM (20) and N (70) while the minimum $(107.63 \mathrm{~cm})$ plant height was recorded from the control treatment. Plant height was increased with the increased use of combined fertilizers. The result was in agreement with Amir Ali Najmetal (2013) reported that the maximum amount of plant height was obtained using 20 ton $\mathrm{ha}^{-1}$ cattle manure.

\section{LEAF LENGTH}

Statistical analysis of the data showed that fertilizers have a significant effect on leaf length of the plant. The data (Table-1) showed that, the maximum $(6.6333 \mathrm{~cm})$ leaf length was recorded in farmyard manure (0) and nitrogen (70) of the fertilizer. While the minimum $(4.5667 \mathrm{~cm})$ leaf length was recorded in the control treatment. However, data showed that leaf length of Potato was increased as the amount of farmyard manure applied increased. The results are in conformity with those of Najm et.,al 2013). 


\section{LEAF NUMBER}

Statistical analysis of the data showed that leaf number of Potato was significantly affected by combined fertilizers (Nitrogen and farm yard manure). The data (Table-1) revealed that the maximum (219.67) of leaf number were recorded in farmyard manure (20) and nitrogen (35) and the minimum (159.77) leaf number was recorded in farmyard manure (0) and nitrogen (35) as supposed by (Hassanpanah and Azimi, 2012).

\section{LEAF DIAMETER}

Analysis of variance indicated that there were highly significant (at p- value of $<0.001$ ) difference on leaf length due to main of nitrogen and interaction of FYM with nitrogen and there was significant (at p- value of $<0.005$ ) difference due to Nitrogen and interaction of FYM and nitrogen. The highest value $(5.0533 \mathrm{~cm})$ of leaf diameter was recorded from a plot applied with $0.02 \mathrm{~kg} / \mathrm{ha}$ without nitrogen. On the other hand lowest value $(3.3767 \mathrm{~cm})$ was obtained when $0.07 \mathrm{~kg} / \mathrm{ha}$ of nitrogen applied without farmyard manure. Statistical analysis of the data showed that leaf diameter increased in plot that farm yard manure applied.

\section{STEM DIAMETER}

Stem diameter of Potato were highly responsive to various combinations of fertilizers FYM and Nitrogen given in Table-1.Statistical analysis of the data showed that the combination of FYM and Nitrogen has a significant effect on stem diameter. The data (Table-1) show that, the maximum $(5.1100 \mathrm{~cm})$ stem diameter was recorded in $(0.02$ and $0.07 \mathrm{k} / \mathrm{ha})$ of FYM and Nitrogen respectively. While the minimum $(2.7417 \mathrm{~cm})$ stem diameter was recorded in control treatment this may be due to absence of FYM and Nitrogen in control treatment.

\section{STEM NUMBER}

Stem number was affected by various rate of fertilizers existed. The data manifested after statistical analysis that stem number has significantly affected by farmyard manure. Statistical analysis of the data showed that all treatments were significantly not different from each other. The data (Table-1) showed that, the maximum (3.333) stem number was recorded in FYM (20) without application of nitrogen. While the minimum (1.6433) of stem number was recorded in the control treatment. The result was in agreement with (Hassanpanah and Azimi, 2012).

\section{CONCLUSION}

The result of this study revealed that the maximum Potato crop height $(128.88 \mathrm{~cm})$, number of stem (3.33), and leaf diameter $(5.0533 \mathrm{~cm})$ recorded in the treatment contain maximum amount of farm yard manure (F20N70). The minimum Potato crop height $(107.63 \mathrm{~cm})$, number of stem (1.6433) was recorded from the control treatment (F0 N0) and leaf diameter $(3.3767 \mathrm{~cm})$ was recorded from maximum amount of nitrogen (F0N70). From the study it could be concluded that Potato crop yield parameters were greatly affected by different rates of fertilizers. Judicious control measures recommended to be adopted that can control different rate of fertilizers (farmyard manure and nitrogen) in Potato crop to reduce the crop yield reduction due to poor soil 
fertilization. Accordingly, from the analyzed data almost all parameters of Potato yield recorded significant differences using various rates of fertilizers. Generally, as the appropriate amount of different rates of fertilizers (farmyard manure and nitrogen) increased, the Potato growth and yield may also increase.

\section{ACKNOWLEDGEMENTS}

The Authors would like to thank Jimma University College of Agricultures and Veterinary Medicine (JUCAVM) for funding the research expenses and providing all the necessary facilities to carry out the research.

\section{REFERENCES}

[1] Ali MR, costa DJ, abedi MJ, sayed MA, andbasak NC. 2009. effect of fertilizer and variety on the yield of sweet potato. Bangladesh J. Agril. Res. 34(3) : 473-480

[2] Amir Ali Najm, Mohammad Reza Haj Seyed Hadi, Mohammad Taghi Darzi, Faezeh Fazeli.2013.Influence of nitrogen fertilizer and cattle manure on the vegetative growth and tuber production of potato. International Journal of Agriculture and Crop Sciences 5(2). 147-154

[3] Asiegbu, J. E. \& Oikeh, S. (1995). Evaluation of chemical composition of manures from different organic wastes and their potential for supply of nutrients to tomato in tropical ultisols. Biological Agric. Horti., 12, 47-60.

[4] Errebhi M, Rosen CJ, Gupta SC, Birong DE. 1998. Potato Yield Response and Nitrate Leaching as Influenced by Nitrogen Management. Agron. J. 90:10-15.

[5] Gebre medhin, W.G, G. Endale and L.Berga, 2008. Root and Tuber crops. EIAR.Addis Ababa Ethiopia

[6] Hassanpanah D, Jafar A. 2012. Evaluation of 'Out Salt' anti-stress material effects on mini-tuber production of potato cultivars under in vivo condition. Journal of Food, Agriculture \& Environment Vol.10 (1): 256 - 259.

[7] Kandil AA, Attia AN, Badawi MA, Sharief AE, Abido WAH.2011. Effect of Water Stress and Fertilization with Inorganic Nitrogen and Organic Chicken Manure on Yield and Yield Components of Potato. Australian Journal of Basic and Applied Sciences, 5(9): 997-1005

[8] Karam F, Rouphacl Y, Lahoud R, Breidi J, Coll G.2009. Influence of Genotypes and potassium Application Rates on Yield and potassium Use Efficiency of Potato. J Agro ; 8(1):27- 32

[9] Leytem AB, Westermann DT.2005. Phosphorus availability to barley from manures and fertilizers on a calcareous soil. Soil Science. 170(6):401-412

[10] Tagoe SO, Horiuchi T, Matsui T. 2008. Effects of carbonized and dried chicken manures on the growth, yield, and N content of soybean. Plant and Soil 306(1): 211-220.

[11] Tamirie, H., 1989. Increasing Agricultural Production in Ethiopia Through Improved Soil. Water and Crop Management Practices. In: Towards a Food and Nutrition Strategy for Ethiopia, Belshaw, D.G.R. (Eds.). ONCCP, Ethiopia, pp: 243-275.

[12] White PJ, Wheatley RE, Hammond JP, Zhang K. 2007.Minerals, soils and roots. In: Vreugdenhil D (ed) Potato biology and biotechnology, advances and perspectives. Elsevier, Amsterdam, pp: 739-752. 